\title{
KONSTRUKSI SEKSUALITAS PEREMPUAN DALAM BERITA PEMERKOSAAN DI TEKS MEDIA DARING
}

\author{
Daniel Susilo \\ Fakultas Ilmu Komunikasi \\ Universitas dr. Soetomo \\ Email: dani.susilo@yahoo.com \\ Eben Haezer \\ Program Magister Media dan Komunikasi Fakultas Ilmu Sosial dan Politik \\ Universitas Airlangga
}

\begin{abstract}
Since 2010, Indonesian media have a significant change in a medium of distribution the message. Slow but sure, online news media became the main favourite choose for accessing the information by Indonesian people. In the same time, rape news in the yellow newspaper became digitalized and moved to online news media. This study uses critical discourse analysis by Van Dijk to show how the media construct the women sexuality in the press text. Researcher uses JPNN.com as the object of the research. Item to be observed are thematic, schematically, semantic, syntactic, stylistic and rhetorical. Results of this research indicates women sexuality as commodity might by men. Besides, the online news site simultaneous reinforce the view "binary opposition" against women, through the elements and media resources under their authority.
\end{abstract}

Keywords: Media text; Rap; Women sexuality.

\begin{abstract}
ABSTRAK
Semenjak tahun 2010, media Indonesia mengalami perubahan besar dalam distribusi pesan yang digunakan. Perlahan namun pasti, situs berita online atau daring menjadi pilihan utama masyarakat Indonesia dalam mengakses informasi. Secara bersamaan pula, berita-berita pemerkosaan yang sebelumnya berada dalam Koran-koran kuning juga terdigitalisasi, berpindah menuju situs berita daring. Penelitian ini menggunakan metode Analisis Wacana Kritis Van Dijk untuk membongkar bagaimana media mengkonstruksi seksualitas perempuan dalam teks media di situs berita online Indonesia, JPNN.com. Hal-hal yang diamati adalah tematik, skematik, semantik, sintaksis, stilistik, dan retoris. Hasil dari penelitian ini mengindikasikan bahwa seksualitas perempuan sebagai sesuatu yang dikuasai laki-laki. Selain itu, situs berita daring secara stimultan meneguhkan pandangan "oposisi biner" terhadap perempuan, melalui elemen-elemen dan sumber daya media yang dikuasainya.
\end{abstract}

Kata Kunci: Pemerkosaaan; Teks media; Seksualitas perempuan. 


\section{PENGANTAR}

Penetrasi internet di Indonesia mengalami lonjakan signifikan pada periode 2012-2014. Kenaikan lebih dari 10\% jika dibandingkan dengan periode sebelumnya. Menurut data yang dirilis APJII (2015: 3), tingkat penetrasi internet Indonesia pada tahun 2012 berada dalam angka 24,23\% dan pada tahun 2014 mengalami lonjakan hingga 34,9\% dengan mayoritas pengguna (49\%) berada dalam usia dewasa muda (18-25 tahun). Oleh APJII (2015:4) pengguna dalam usia ini dikategorikan sebagai pengguna internet aktif yang lahir dalam era yang disebut digital native.

Data lain yang dipaparkan oleh Aliansi Jurnalis Independen pada tahun 2014 menyatakan bahwa telah terjadi perubahan tren pada masyarakat dalam mengakses berita. Akses yang sebelumnya dilakukan dengan metode konvensional (koran, televisi, radio) menjadi digital pada situs-situs berita daring (Margianto dan Syaefullah 2012: 38-39). Data AJI ini sejalan dengan pertumbuhan internet yang dipaparkan dalam data APJII. Meningkatnya penetrasi internet menggeser pola akses berita dalam masyarakat. Perubahan ini juga mendorong beberapa raksasa media mulai menginfiltrasi situs berita daring guna mempertahankan eksistensinya dalam industri media. Raksasa media Kompas Gramedia yang sebelumnya mengukuhkan dirinya dalam jajaran papan atas media cetak lewat Harian Kompas dan Jaringan Persda (Tribunnews) menelurkan jaringan berita daring Kompas. com dan Tribunnews.com. Demikian pula jaringan Jawa Pos, yang pada tahun 2012 berkeyakinan bahwa media cetak tetap akan mendominasi industri pers, mulai berbalik arah pada tahun 2015 dengan serius menggarap JPNN.com sebagai jaringan media daringnya.

Pertumbuhan situs media daring yang melesat di Indonesia juga membawa beberapa dampak serius dalam bagaimana media merepresentasikan seksualitas dalam berita-berita yang disajikan. Susilo (2014: 19) menjelaskan bahwa seksualitas perempuan adalah objek yang menguntungkan bagi media untuk dikomersilkan dan dieksploitasi. Susilo (2014: 19-20) menuturkan dalam mem- beritakan perempuan, media daring memposisikan perempuan sebagai objek seks dengan menampilkan sisi-sisi sensasional yang tak jarang peliputan tersebut bernuansa pornografi.

Seksualitas perempuan dimaknai sebagai objek yang komersil dan layak untuk dimaknai sebagai sesuatu yang disebut previlege bagi lakilaki. Pandangan tersbeut tidak dapat dilepaskan dari pelabelan yang cenderung beroposisi biner dan selalu dilekatkan dalam tubuh perempuan. Label "perempuan baik-baik" dan "bukan perempuan baik-baik" menjadi pelabelan yang sedemikian mudah dilakukan media terhadap perempuan (Santi, 2006: 7-8). Perempuan yang mengalami tindakan perkosaan dengan mudahnya dilabelkan "bukan perempuan baik-baik" dengan kacamata yang bertendensi maskulin.

Susilo (2015: 223) memberikan pemaparan bahwa pemberitaan dalam media daring berupaya untuk memberikan kepuasan fantasi dan imaji seksualitas kepada para pembaca berita perkosaan. Upaya tersebut diwujudkan dalam pendetilan narasi-narasi berita-berita perkosaan sehingga pembaca dirangsang seolah-olah pembaca turut menyaksikan perkosaan tersebut. Pemberitaan dengan cara semacam itu menajdi upaya-upaya media daring menaikkan jumlah pengunjung dan tingkat berbagi (share) berita tersebut. Wood (2005: 232-233) menjelaskan bahwa dalam memandang seksualitas perempuan, media berkecenderungan bias dengan melabelkan perempuan sebagai sosok yang dramatis dan sangat tepat dalam posisi yang berperan sebagai korban. Wood (2005: 235) menjelaskan dalam memahami seksualitas perempuan yang ditampilkan media, perlu memberikan fokus pada media yang menggambarkan seksualitas perempuan berada dalam subordinasi seksualitas laki-laki yang bertendensi maskulin. Perempuan menjadi sosok yang direpresentasikan lemah dan tidak layak merepresentasikan seksualitasnya karena praanggapan bahwa seksualitas perempuan tabu untuk direpresentasikan oleh perempuan sendiri.

Kerancuan cara pandang ini menyebabkan media berputar-putar pada kerangka 
kapitalisasi atas seksualitas perempuan. Media menjadi tidak peduli dan tidak sensitif pada seksualitas perempuan. Semata-mata seksualitas perempuan tersebut direpresentasikan hanya untuk kepentingan kenaikan jumlah kunjungan pada situs.

Dalam penelitian yang dilakukan Brooks, et.al. (2006: 297-317), pemilihan kata yang bertendensi kepada pada sisi maskulinitas menjadi hal yang lazim ditemui dalam media kita hari ini. Brooks, et.al. menjelaskan mengenai temuan unik terhadap representasi perempuan Asia pada media. Perempuan Asia digambarkan sebagai sesuatu yang sensual, eksotis, dan berfungsi sebagai pemuas hasrat lelaki (lotus blossom) atau sebagai mitra untuk melakukan kejahatan (dragon ladies) dalam media mainstream. Brooks, et.al. menjelaskan lebih lanjut bahwa perempuan Asia digambarkan dalam sosok yang "penurut/ patuh" didalam konteks relasi dengan laki-laki. Brooks, et.al. menyimpulkan bahwa representasi perempuan dalam media yang tidak signifikan. Dalam berbagai riset, penelitian representasi perempuan Asia di media sangat jarang karena minimnya prosentase representasi perempuan tersebut. Representasi tersebut masih terbatas pada perempuan yang dijadikan obyek pemuas hasrat yang sensual serta partner laki -laki dalam melakukan kejahatan.

Pendataan yang dilakukan National Crime Victim Survey (Aditya, 2016:49), kelompok rentan yang mengalami perkosaan, percobaan perkosaan maupun pelecehan seksual adalah kelompok remaja perempuan usia 16-19 tahun, dan mereka memiliki kerentanan 4 kali lebih sering dibanding kelompok usia lainnya. Dalam catatan lainnya, Aditya (2016:48 - 49) menjelaskan bahwa seringkali kekerasan seksual (pemerkosaan) dikonstruksi dan dilekatkan pada jenis kelamin tertentu (perempuan), dan baru diketahui oleh masyarakat saat media masa secara massif memberitakannya.

Perempuan dan tubuhnya menjadi bagian yang salah, tubuh perempuan dianggap sebagai bagian dari kerangka besar tentang seksualitas yang menjadi tidak layak diperbincangkan perempuan sendiri (Butler 2011a:157). Dalam pandangan Butler (2011b: 51) perbincangan mengenai tubuh dan seksualitas perempuan berkaitan erat dengan relasi tidak seimbang dalam penggunaan bahasa yang berlabel feminim dan maskulin. Kata-kata yang berlabelkan feminim berujung pada penggunaan kata diperkosa, digauli, dicabuli, dibakar erat diberikan media pada perempuan yang berkaitan langsung sebagai objek dari aktivitas kekerasan seksual. Kata-kata tersebut menggambarkan konsep bahwa seksualitas perempuan dianggap pasif. Sebaliknya katakata yang berlabelkan maskulin dapat dengan mudah ditemui di media pada penggunaan kata yang berlawanan dengan kata-kata feminim di atas. Penggunaan kata memperkosa, menggauli, mencabuli, membakar adalah katakata yang merepresentasikan sifat aktif dari seksualitas laki-laki.

Perbincangan mengenai tubuh perempuan yang dianggap pasif juga diperbincangkan Ansor dan Meutia (2016: 161-162) dalam sudut pandang agama. Ansor dan Meutia menemukan tubuh perempuan yang dipaksakan menggunakan atribut keagamaan tertentu. Perempuan yang tubuhnya tidak menggunakan atribut tersebut ditekan oleh masyarakat sebagai tubuh yang "salah" (Ansor dan Meutia 2016: 166-167).

Sementara itu, dalam perjalanan teori feminisme pun juga mengalami minat luar biasa dalam perkembangan analisis struktural. Jackson (2009: 37) menjelaskan bahwa perbincangan ideologi dalam analisis gender tidak dipandang sebagai cerminan superstruktur dari basis ekonomi masyarakat. Dengan kata lain, diskusi mengenai subordinasi perempuan tidak selalu harus menghubungkan konteks produksi (kapital).

Penelitian ini berfokus pada bagaimana seksualitas perempuan direpresentasikan, diproduksi, dan didistribusikan dalam teks-teks berita pemerkosaan pada situs berita daring. Penelitian ini bertujuan untuk mengkritik penggambaran seksualitas perempuan dalam teks berita pemerkosaan di situs berita daring. Penelitian ini secara spesifik menggunakan data berita yang dimiliki JPNN.com pada rentang 
pemberitaan Januari 2016-Agustus 2016 (enam bulan). Peneliti secara khusus menggunakan JPNN.com sebagai objek penelitian karena JPNN.com didukung oleh lebih 500 wartawan daerah yang menjadi jaringan dari korporasi media Jawa Pos Group (JPNN.com).

Berita-berita tersebut secara khusus diolah dan dilakukan penyaringan untuk memenuhi kriteria objek berita yang akan digunakan dalam penelitian ini, yakni berita pemerkosaan. Kemudian berita-berita pemerkosaan tersebut dipilah- pilah dan diklasifikasikan yang paling signifikan dalam merepresentasikan seksualitas perempuan. Dari pemilahan dan penyaringan dengan kategorisasi yang ditetapkan peneliti sebelumnya, ditemukan tiga berita yang dapat merepresentasikan penggambaran seksualitas perempuan dalam kasus berita perkosaan. Berita yang telah diklasifikasi tersebut dianalisis menggunakan metode Analisis Wacana Kritis Teun A. Van Dijk yang memfokuskan pada pembedahan struktur wacana, komponen, dan unsur-unsur wacana secara lebih terperinci. Pemilihan Metode Analisis Wacana Kritis milik Van Dijk dimaksudkan untuk dapat secara jernih dan detil merinci struktur wacana yang tersembunyi dalam teks media. Dalam analisis wacana kritis, teks dianggap aktif berbicara dan mengkonstruksi dunia sosial (Van Dijk 2001:11)

Dalam analisis wacana Van Dijk, terdapat tiga hal penting yang berpengaruh terhadap produksi dan analisis wacana, yaitu ideologi, pengetahuan dan wacana. Ideologi menjadi penting karena pada dasarnya tidak ada wacana yang benar-benar netral dari ideologi penuturnya. Sementara pengetahuan (Suriasumantri, 2013:53) menurut pandangan kaum empirisme adalah kepercayaan yang dijustifikasi atau telah dibuktikan kebenarannya secara empiris. Namun pengetahuan bagi sebuah kelompok belum tentu adalah pengetahuan bagi kelompok yang lainnya karena tidak semua kelompok mengalami pengalaman yang sama.

Dalam produksi wacana, struktur pengetahuan mengontrol semantik dan perangkat wacana yang lain. Menurut Kuntoro (2008:46), pengetahuan itu tidak cuma terkait dengan penutur, melainkan juga berkaitan dengan pengetahuan lain yang dimiliki pendengar, pembaca, maupun partisipan, maka diperlukan sebuah model yang kompleks tentang situasi pengetahuan lain dari peristiwa komunikatif yang disebut dalam konteks.

Lebih lanjut, Van Dijk (2001:11) menyebutkan bahwa wacana memiliki tiga dimensi yaitu teks, kognisi sosial, serta konteks sosial. Karena itu, kunci dari analisis wacana adalah menggabungkan tiga dimensi itu ke dalam sebuah kesatuan. Dalam dimensi teks, yang diteliti adalah bagaimana struktur teks dan strategi wacana, dipakai untuk menjustifikasi tema tertentu. Sementara dalam dimensi kognisi sosial, yang dipelajari adalah proses produksi berita yang melibatkan kognisi individu penulis berita. Terakhir, dimensi ketiga, yang dipelajari adalah bangunan wacana yang berkembang di masyarakat.

Memahami pendekatan kritis Van Dijk (Lehtonen, 2007) juga dapat dapat dianggap sebagai pendekatan konstruktivis sosial yang menyatakan bahwa representasi dunia bersifat linguistis diskursif, makna yang bercenderungan memiliki sifat historis dan pengetahuan sendiri diciptakan melalui interaksi sosial. Van Dijk (2001:11) menjelaskan bahwa dalam penelitian analisis wacana kritis mengambil posisi melawan arus besar guna melawan ketidakadilan sosial. Unsur- unsur yang diamati dalam penelitian ini adalah tematik, skematik, semantik, sintaksis, stilistik, dan retoris (Sobur, 2001: 74).

\section{PEMBAHASAN \\ Perempuan sebagai Obyek: Eksploitasi Seksualitas}

Poerwandari (2016: 44) menyatakan bahwa perempuan mudah dikenai stigma buruk karena berbagai hal seperti pulang malam, mengenakan busana yang tidak tertutup, dan bergaul bebas dengan laki-laki. Oleh karena itu, ketika mereka bergaul secara bebas dengan seorang lelaki yang latar belakangnya tidak jelas, perempuan kerap dianggap sebagai seseorang yang hina dan pantas dijadikan obyek semata.

Dalam mengurai permasalahan perempuan sebagai obyek, peneliti menggunakan 
berita yang dimuat oleh JPNN.com dalam tautan: http://www.jpnn.com/ $\mathrm{read} / 2016 / 03 / 24 / 365548 /$ Cewek-ABGDiperkosa-Usai-Digerebek-Berdua-duaan-, diakses 23 Agustus 2016. Berita tersebut ditulis pada 24 Maret 2016. Berita ini dikategorikan dalam rubrikasi Kriminal oleh redaksi JPNN. Berita ini diberi judul: "Cewek ABG Diperkosa Usai Digerebek Berdua-duaan".

Selanjutnya, berita ini akan dibedah unsurunsur tematik, skematik, semantik, sintaksis, stilistik, serta retorisnya.

\section{Tematik}

Berita ini memiliki topik mengenai kemalangan (perkosaan) yang menimpa perempuan yang awalnya berduaan dengan seorang laki-laki beristri, namun digerebek salah satu ketua organisasi kepemudaan. Usai diinterograsi oleh ketua organisasi tersebut, dengan dalih mengamankan perempuan tersebut, pelaku malah memperkosaan korban. Berita ini menggunakan kata cewek sebagai kata ganti perempuan (korban perkosaan). Pemilihan kata ganti yang digunakan oleh jurnalis menunjukkan ketidakempatian jurnalis terhadap korban perkosaan. Kata cewek merupakan kata slang yang menujukkan perendahan diri atas keperempuanan korban bagi yang mengucapkan terhadap mereka yang dilabelkan kata tersebut. Dari keseluruhan berita ini, tidak pernah disebutkan "korban" sebagai perempuan ataupun penyebutan kata korban.

Kealpaan kata "korban" dalam berita ini menunjukkan jurnalis dan redaksi menganggap kemalangan yang menimpa korban bukanlah sesuatu yang membuat korban menjadi "korban". Dalam aktivitas pelecehan seksual tersebut, seksualitas perempuan (korban) adalah previlege bagi pelaku perkosaan.

\section{Skematik}

Dijadikannya korban perkosaan semata sebagai obyek, terlihat sejak awal dalam penyusunan berita. Dalam berita tersebut, sebenarnya terdapat lebih dari satu sudut pandang. Pertama, sudut pandang dilaporkannya seorang anggota ormas ke- pemudaan karena memperkosa, serta sudut pandang diperkosanya seorang perempuan setelah dia digerebek karena diduga berselingkuh saat berduaan dengan seorang pria beristri. Pemilihan sudut pandang ini menentukan di mana perempuan yang menjadi korban perkosaan ditempatkan. Apabila yang dipakai adalah sudut pandang pertama, maka titik tekannya adalah kesewenang-wenangan seorang lelaki yang adalah tokoh ormas kepemudaan terhadap perempuan. Apabila yang dipakai adalah sudut pandang kedua, maka titik tekannya adalah menempatkan perkosaan itu sebagai akibat dari kesalahan perempuan yang menjadi korban.

Pada akhirnya, yang dipakai dalam pemberitaan itu adalah sudut pandang kedua. Hal ini terlihat dari kalimat pertama di paragraf pertama yang susunannya adalah : "Seorang cewek berusia 16 tahun inisial Ni digerebek sedang berduaan dengan pria beristri." Setelah kalimat ini, selanjutnya berita disusun berdasarkan kronologi yang sumbernya tidak jelas.

Akan tetapi, patut diduga bahwa rincian kronologi itu hanya bersumber dari polisi. Hal ini terlihat dari satu-satunya kutipan pernyataan di berita itu yang berasal dari Paur Humas Polres Pelalawan, Ipda M Sijabat SH. Dalam kutipan itu, polisi menyatakan bahwa tersangka telah ditahan setelah pemeriksaan dilakukan terhadap sejumlah saksi.

Diletakkannya kutipan tersebut di bagian paling akhir, semakin menunjukkan bahwa jurnalis tidak memiliki akses sama sekali untuk mewawancarai korban maupun pelaku. Padahal, apabila jurnalis yang bersangkutan memiliki akses ke sana, susunan berita yang dibuat bisa beragam dan terbuka kemungkinan untuk menyusun sebuah berita yang lebih menempatkan perempuan korban perkosaan tersebut pada posisi yang bukan semata sebagai obyek.

Ketiadaan akses untuk mewawancarai korban bisa terjadi karena beberapa hal. Pertama, keengganan jurnalis untuk menggali informasi yang lebih komprehensif. Kedua, terbatasnya akses untuk mewawancarai. Dalam kancah jurnalistik, terbatasnya akses untuk mewawancarai korban perkosaan (terlebih 
yang secara hukum masih dinyatakan di bawah umur) disebabkan karena penafsiran yang beragam atas Undang-Undang Nomor 35 tahun 2014 tentang Perubahan atas Undang-Undang Nomor 23 tahun 2002 tentang Perlindungan Anak. Dalam pasal 64 ayat (1) huruf i, dituliskan bahwa Perlindungan khusus bagi anak yang berhadapan dengan hukum sebagaimana dimaksud dalam pasal 59 ayat (2) hurufb dilakukan melalui penghindaran dari publikasi atas identitasnya.

Ayat tersebut, seringkali ditafsirkan baik oleh aparat penegak hukum maupun oleh jurnalis, bahwa anak-anak yang berhadapan dengan hukum, baik sebagai pelaku maupun korban, harus disembunyikan identitasnya sepenuhnya. Karena dianggap harus disembunyikan, maka polisi seringkali menganggap bahwa yang bersangkutan tidak dapat diwawancarai oleh media. Sementara bagi jurnalis, tidak cukup tahu bahwa penyembunyian identitas ini bukan berarti bahwa seorang anak yang menjadi korban kejahatan seksual sama sekali tidak boleh diwawancarai.

\section{Semantik}

Elemen semantik terdiri dari latar, detil, maksud, serta praanggapan. Latar adalah bagian yang dapat berpengaruh terhadap arti yang ingin ditunjukkan. Bagaimana pilihan latar akan menentukan ke arah mana persepsi pembaca akan dibawa. Umumnya, latar ditampilkan pada bagian awal. Dalam pemberitaan tersebut di atas, pembaca akan dibawa pada persepsi bahwa pemerkosaan terjadi karena kesalahan perempuan tersebut yang sebelumnya dipergoki berduaan dengan seorang laki - laki yang sudah memiliki istri. Hal tersebut, salah satunya muncul karena tidak dijelaskan sama sekali apa maksud dari tindakan perempuan saat berdua-duaan dengan seorang laki - laki yang sudah beristri. Apakah benar itu adalah perselingkuhan atau karena ada maksud dan kegiatan lain, sama sekali tidak diberikan penjelasan.

Sedangkan detil, dalam berita tersebut terkandung dalam kronologi peristiwa yang dimulai dari ketika korban perkosaan digerebek sedang berduaan, hingga ketika keluarganya melaporkan kejahatan seksual yang dilakukan oleh pelaku pada pihak kepolisian. Dalam detil tersebut, ada praanggapan dari jurnalis bahwa kejahatan seksual yang dilakukan oleh pelaku adalah karena niat jahat yang muncul tiba-tiba karena didorong oleh situasi di sekitarnya. Hal ini terlihat dari rangkaian kalimat "Entah kenapa, tiba-tiba muncul niat jahat EN. Apalagi di rumah, mereka hanya berdua. Tanpa pikir panjang, diperkosanya Ni. Usai melampiaskan nafsunya, EN memperbolehkan pulang."

Dengan pernyataan yang demikian, jurnalis memperlihatkan bahwa kesalahan bukan pada pelaku, melainkan karena kondisi yang mendukung, yaitu rumah yang sepi dan hanya ditinggali oleh mereka berdua (pelaku dan korban). Dengan dalih "situasi yang mendukung", jurnalis secara tidak langsung melakukan pembenaran tindakan pelaku yang memperkosa korban.

\section{Sintaksis}

Dalam analisis wacana, sintaksis yang merupakan pertalian antarkata, antar kalimat, maupun antarparagraf, untuk menghubungkan dua paragraf yang saling berlainan. Dalam berita tersebut di atas, sintaksis cukup minim. Namun penggunaan kalimat teras (lead) yang disusun "Seorang cewek berusia 16 tahun inisial Ni digerebek sedang berduaan dengan pria beristri" adalah digunakan untuk menyelaraskan gagasan utama dalam berita tersebut yang sebelumnya tertuang dalam judul: "Cewek ABG Diperkosa Usai Digerebek Berdua-Duaan". Penggunaan judul itu sendiri memperlihatkan bahwa seolah-olah pemerkosaan itu terjadi karena kesalahan perempuan yang menjadi korban, bukan pada niat jahat pelaku.

\section{Stilistik}

Stilistik adalah elemen yang terkait dengan pemilihan kata. Dalam berita tersebut perempuan ditempatkan semata -mata sebagai obyek. Hal ini terlihat dari penggunaan kata-kata pasif seperti digerebek, diinterogasi, diperkosa, dipergoki, dibawa, dan dilepas. Penggunaan pilihan kata ini memperlihatkan bahwa dalam berita tersebut, sosok perempuan yang menjadi korban adalah semata-mata obyek 
yang tidak memiliki kuasa. Perempuan sebagai obyek eksploitasi ini dinaikkan oleh jurnalis dalam meja redaksi dan dikapitalisasi guna kenaikan tiras. Dalam sudut pandang lain, peneliti menilai hal ini tidak hanya faktor ketidakmampuan jurnalis untuk berempati terhadap korban. Hal tersebut juga bisa terjadi karena tidak adanya akses dari jurnalis terhadap korban.

\section{Retoris}

Elemen retoris berkaitan dengan ekspresi untuk menonjolkan maupun untuk menghilangkan bagian tertentu dari sebuah teks. Elemen ini berfungsi untuk menampilkan citra mengenai pihak yang ditonjolkan ataupun yang dimarginalkan. Dalam berita tersebut di atas, penonjolan dilakukan dengan pemilihan judul yang diberi cetak tebal: "Cewek ABG Diperkosa Usai Digerebek Berdua-Duaan". Penonjolan ini, seperti disebutkan sebelumnya, memperlihatkan bahwa dalam berita tersebut perempuan adalah pihak yang diposisikan bersalah, bahkan saat dia telah diperkosa sekalipun. Penggunaanjudul yang tidak sensitif terhadap seksualitas perempuan ini juga mengindikasikan kemalangan yang diterima korban dikapitalisasi media guna kenaikan tiras pengunjung situs berita daring JPNN. Dengan judul yang menonjolkan kesalahan kemalangan ditimpakan pada perempuan akan membuat fantasi pembaca terarah pada tendensi budaya patriarki yang memposisikan perempuan sebagai sumber dari kesalahan.

\section{Perempuan sebagai Obyek: Tidak Memiliki Kuasa dalam Memilih}

Penempatan perempuan sebagai obyek juga tampak dalam pemberitaan JPNN berjudul: "Cinta Ditolak, Pria 45 Tahun Perkosa, Bunuh Lalu Bakar Balita" yang ditayangkan pada 12 Agustus 2016 dengan alamat url: http:/ / www. jpnn.com/read/2016/08/12/460458/CintaDitolak-Pria-45-Tahun-Perkosa-Bunuh-LaluBakar-Balita-

Seperti subbab sebelumnya, berita ini pun akan dibedah unsur-unsur tematik, skematik, semantik, sintaksis, stilistik, serta retorisnya.

\section{Tematik}

Berita berjudul Cinta Ditolak, Pria 45 Tahun Perkosa, Bunuh Lalu Bakar Balita mengandung topik kekerasan seksual yang dilakukan oleh seorang laki - laki karena cinta yang ditolak. Topik ini langsung muncul dalam judul yang dipakai, terindikasi dari dua kata pertama yang dipergunakan adalah Cinta Ditolak sebagai penyebab, dan pemerkosaan, pembunuhan, serta pembakaran, sebagai dampak.

Penolakan cinta yang dimaksud dalam berita tersebut bukanlah penolakan yang dilakukan oleh korban, melainkan oleh kakak korban. Dalam hal ini, terlihat adanya sebuah anggapan yang digiring oleh jurnalis kepada pembaca bahwa pelaku pemerkosaan juga merupakan korban yang telah disakiti perasaannya oleh perempuan. Dengan itu, pelaku merasa berhak untuk membalas perasaan sakit hati itu dengan cara menyakiti orang lain yang memiliki kedekatan hubungan dengan perempuan yang disukainya. Pelaku tidak peduli bahwa korban yang diperkosa dan dibunuhnya sama sekali tidak terlibat dalam peristiwa yang terjadi antaranya dengan kakak korban. Dari paparan ini, terlihat bahwa pelaku menganggap bahwa perempuan seharusnya menuruti keinginan laki - laki. Apabila tidak, maka laki - laki berhak melakukan apa saja, bahkan kekejian sekalipun.

Anggapan ini tampaknya diamini pula oleh jurnalis yang menyusun berita tersebut. Sebab apabila tidak, maka judul yang dibuat tentunya tidak akan menonjolkan alasan pelaku melakukan kejahatannya. Sebenarnya jurnalis memiliki alternatif judul lain yang lebih sesuai inti dalam berita tersebut, misalnya: "Laki-laki 45 Tahun Pemerkosa dan Pembunuh Balita Terancam Hukuman Mati".

Selain itu, dalam berita tersebut terkandung pandangan dari pelaku ataupun jurnalis bahwa pemerkosaan adalah sebuah tindakan yang masih lebih ringan kadarnya daripada pembunuhan. Hal ini terlihat dari paragraf kelima yang ditulis demikian: "Niat membunuh muncul setelah saya bonceng korban (N). Awalnya, hanya niat memerkosa, setelah itu muncul niat membunuh," kata I di laman Kaltim Post, Kamis (11/8). 
Penggunaan kata "hanya" dalam kalimat tersebut, seakan merupakan penekanan bahwa pemerkosaan dan pembunuhan adalah kejahatan yang memiliki derajat berbeda. Atau dengan kata lain, sebuah kejahatan dianggap lebih ringan dari kejahatan lainnya, atau sebaliknya. Padahal dalam pandangan hukum positif, tidak pernah disebutkan bahwa pemerkosaan adalah sebuah kejahatan yang lebih baik daripada pembunuhan, ataupun sebaliknya. Meski sanksi yang diberikan secara hukum memang berbeda, namun bagi korban maupun keluarganya, keduanya sama-sama memiliki dampak yang sama-sama menyakitkan.

Perempuan sebagai korban acapkali diposisikan bersalah sebagai pihak yang kotor dan hina yang tidak memiliki kuasa untuk menentukan pilihan (Poerwandari, 2016:27). Dalam berita ini, perempuan menerima ganjaran atas ditolaknya cinta, serta dianggap layak diperkosa oleh pelaku. Pembenaran semacam ini seringkali dianggap senjata ampuh oleh pelaku tindakan kekerasan terhadap perempuan sebagai dalih meloloskan diri dari upaya hukum.

\section{Skematik}

Berita berjudul "Cinta Ditolak, Pria 45 Tahun Perkosa, Bunuh Lalu Bakar Balita", dibuka dengan paragraf pembuka sebagai berikut: "I (45) dijerat pasal berlapis karena membunuh balita lucu N beberapa waktu lalu. Kasus pemerkosaan dan pembunuhan yang dilakukan warga Sangkulirang, Kaltim itu sudah masuk ke kejaksaan, Rabu (10/8).

Paragraf pembuka tersebut menjadi ganjil karena tidak sesuai dengan penonjolan yang sebelumnya dilakukan melalui judul. Dalam paragraf pertama berita itu, tidak disebutkan mengenai alasan mengapa kejahatan seksual dilakukan. Padahal dalam kaidah yang umum berlaku di jurnalistik, berita yang bersifat straight news atau berita langsung, selalu diawali dengan paragraf yang berisi intisari dari berita, yang umumnya memiliki kesesuaian dengan judul yang dibuat. Dengan demikian, meski tidak bisa menonjolkan alasan terjadinya kekerasan seksual dalam paragraf pertama, terlihat bahwa jurnalis penulis berita itu tetap memaksakan penonjolan melalui judul.

Penonjolan lewat judul tetap dilakukan meski sama sekali tidak sesuai dengan paragraf pertama karena penulis ingin pembaca tertarik untuk membuka tautan yang dibagikan untuk membaca keseluruhan berita tersebut. Dengan judul yang bombastis sekaligus memancing emosi, akan menggiring pembaca untuk mengetahui kisah lebih lengkap dari peristiwa tersebut. Pada akhirnya, penggiringan ini memiliki nilai ekonomi (kapitalisasi) karena setiap kunjungan pembaca ke berita tersebut akan bisa diakumulasikan sebagai tawaran kepada calon pemasang iklan. Tawaran yang diberikan kepada pemasang iklan adalah tingginya kunjungan pembaca.

\section{Semantik}

Berita berjudul Cinta Ditolak, Pria 45 Tahun Perkosa, Bunuh Lalu Bakar Balita, memiliki latar penolakan cinta dari seorang perempuan yang menyebabkan seorang pria melakukan kekerasan seksual dan pembunuhan terhadap seorang balita. Hal tersebut selain diperkuat oleh judul, juga diperkuat dengan detil yang masuk dalam beberapa paragraf berikutnya. Salah satunya adalah paragraf ke 6 yang ditulis demikian: "Niat itu muncul karena saya dendam dengan kakak korban. Saya suka kakak korban, tapi kakaknya tidak menerima saya," imbuhnya.

Dengan latar dan detil yang demikian, lagi-lagi pembaca digiring pada persepsi bahwa pemerkosaan itu bukanlah semata kesalahan pelaku, melainkan juga mengandung kesalahan perempuan yang menolak cintanya. Padahal, perempuan juga memiliki hak untuk memilih siapa sosok laki-laki yang akan dijadikannya pasangan dan mana yang tidak.

\section{Sintaksis}

Elemen sintaksis dalam berita tersebut terbilang cukup minim karena pola hubungan dari satu paragraf ke paragraf lainnya berlangsung linier. Linearitas ini terjadi karena narasumber yang diwawancarai langsung dalam berita tersebut hanya satu orang, yaitu Kepala Kejari Sangatta, Tety Syam. Sementara, pernyataan dari pelaku yang kemudian 
dikutip dalam paragraf kelima dan keenam, tidak bersumber dari wawancara langsung, melainkan dari mengutip wawancara yang dilakukan oleh media lain.

\section{Stilistik}

Dalam berita di atas, elemen stilistik yang terkait dengan pemilihan kata, paling terlihat dalam penggunaan judul: "Cinta Ditolak, Pria 45 Tahun Perkosa, Bunuh Lalu Bakar Balita". Kalimat dalam judul tersebut mengandung tiga kosakata yang berkonotasi negatif, yaitu "perkosa", "bunuh", dan "bakar". Sebelum tiga kata tersebut dimunculkan, penulis berita mendahuluinya dengan dua kata yaitu "cinta ditolak". Pemilihan dua kata ini untuk mendahului keterangan yang menyatakan apa yang telah diperbuat pelaku, mengesankan bahwa karena hal yang sepele dalam hal ini penolakan cinta dapat menjadi pemicu timbulnya pembenaran untuk melakukan kejahatan. Padahal, penolakan tidak bisa disebut sebagai hal yang sepele karena pada dasarnya setiap perempuan berhak untuk menentukan masa depannya, termasuk dalam memilih pasangan. Dengan menganggap penolakan itu sebagai hal yang sepele, menunjukkan adanya pengingkaran ataupun penyangkalan terhadap hak perempuan untuk menentukan hidupnya sendiri.

\section{Retoris}

Dipandang dari elemen retorisnya, pada berita di atas yang paling banyak dikemukakan adalah sudut pandang pelaku. Sementara, sudut pandang orang lain yang mewakili korban hilang. Padahal dengan mengetahui sudut pandang orang lain yang mewakili korban (misalnya kakak korban yang sebelumnya mennolak cinta pelaku) bisa didapatkan gambaran yang lebih luas mengenai karakter pelaku sehingga kemudian muncul alternatif sudut pandang berita yang tidak terkesan menyalahkan perempuan dan menempatkan perempuan pada posisi yang harus menerima segala keinginan laki-laki.

\section{Perempuan sebagai Obyek: Perempuan yang Tidak Berdaya}

Lebih lanjut, posisi perempuan sebagai obyek juga semakin diperkuat dalam berita ketiga berjudul "Pacar Hamil 3 Bulan, Dihajar Sampai tak Berdaya, Lalu Diperkosa". Pada JPNN.com, berita ini ditayangkan pada 17 Agustus 2016 dengan alamat url http:/ / www. jpnn.com/read/2016/08/17/461522/PacarHamil-3-Bulan-Dihajar-Sampai-tak-BerdayaLalu-Diperkosa-. Untuk menjelaskan argumen tersebut, kembali akan dibedah elemen-elemen tematik, skematik, semantik, sintaksis, stilistik, dan retorisnya.

\section{Tematik}

Berita berjudul "Pacar Hamil 3 Bulan Dihajar Sampai tak Berdaya, Lalu Diperkosa", mengandung topik kekerasan yang dilakukan seorang laki-laki terhadap seorang perempuan. Kekerasan itu terjadi lebih dari sekali, yaitu ketika pelaku membujuk korban untuk melakukan hubungan seksual ketika pelaku menganiayanya karena terus menerus dimintai pertanggungjawaban setelah korban mengetahui bahwa dirinya sedang hamil tiga bulan, serta ketika korban disetubuhi saat pingsan seusai dianiaya secara fisik. Topik tersebut lantas disederhanakan dalam sebuah kalimat yang kemudian dipilih sebagai judul.

Judul itu sendiri mengandung kalimat pasif yang semuanya menunjuk pada korban, bukan pelaku. Andai penulis menggunakan kalimat aktif yang sudut pandangnya adalah pelaku, maka judulnya dapat diganti, misalnya demikian: "Pelajar SMK Menganiaya dan Memperkosa Kekasihnya yang Hamil 3 Bulan". Pemilihan judul yang menggunakan kalimat pasif dengan sudut pandang korban, memiliki makna dan dampak yang luas. Hal ini sama dengan mengeksploitasi kemalangan yang dialami korban. Sangat terbuka kemungkinan bahwa pemilihan judul yang demikian akan berdampak terhadap kondisi psikologis korban dan keluarganya apabila mereka membaca berita tersebut. Pemilihan judul yang demikian memperlihatkan bahwa empati terhadap korban kekerasan seksual masih belum cukup ditunjukkan oleh penulis berita. 


\section{Skematik}

Setelah dibuka dengan judul yang menggunakan kalimat pasif yang mengeksploitasi kemalangan korban, berita ini dibuka dengan paragraf pertama yang demikian: MDA tega menganiaya sang kekasih DD setelah mengetahui remaja 17 tahun itu hamil tiga bulan, Selasa (16/7). Sebelum melakukan aksinya, pelajar salah satu SMK negeri di Batam itu sudah menyusun siasat. Pemilihan susunan kata dalam paragraf pertama itu sama sekali berbeda dengan judul yang sebelumnya ditulis. Padahal dalam kaidah jurnalistik yang umum berlaku, penulisan berita straight news atau berita langsung, paragraf pertama sebuah berita harus memuat inti yang ditampilkan lewat judul. Dengan pemilihan paragraf yang demikian menjadikannya semakin terlihat bahwa judul yang sebelumnya dibuat hanyalah untuk membuat orang tertarik untuk membaca. Lagi-lagi, ini adalah bentuk eksploitasi media terhadap duka yang dialami oleh korban kekerasan seksual.

Pada paragraf-paragraf berikutnya, berita ini lebih banyak mengungkapkan kronologi peristiwa sejak ketika pelaku dan korban bertemu di belakang sebuah rumah makan bernama Bahagia 2 di Batubesar, Nongsa, hingga ketika korban berhasil melarikan diri dan pelaku ditangkap. Namun, dalam penyingkapan kronologi ini, tidak terungkap satupun pernyataan korban maupun pelaku. Pengungkapan kronologi atau kisah dari sebuah peristiwa yang tidak bersumber dari narasumber utama yang pada dasarnya sangat tidak disarankan dalam sebuah kegiatan jurnalistik karena dapat menyebabkan informasi menjadi bias. Apabila informasi bias, penulis memiliki kebebasan untuk mengolah data-data yang dimilikinya, bahkan meskipun dalam melakukan pengolahan itu terjadi percampuran antara fakta, opini, dan imajinasi.

\section{Semantik}

Ditinjau dari elemen semantiknya, berita tersebut hanya berusaha untuk menghidupkan suasana saat kekerasan terhadap korban berlangsung, namun tidak memberi ruang untuk menghadirkan empati terhadapnya.
Hal ini terlihat dari latar yang dipilih hanya menggambarkan suasana tempat kejadian dan aktivitas pelaku serta korban yang sedang berlangsung di tempat kejadian.

Sementara dalam hal detilnya, berita tersebut banyak mengumbar detil kronologis, misalnya bagaimana pelaku melakukan kejahatannya dan alat-alat apa yang dipergunakan untuk hal tersebut.Selainitu, sejakawal dalam paragraf pertama, penulis menonjolkan bahwa kejahatan pelaku dilakukan karena dirinya tidak bisa menerima kenyataan bahwa korban yang adalah kekasihnya sendiri, sedang hamil tiga bulan akibat hubungan seksual yang mereka lakukan sebelumnya. Dari sini muncul praanggapan bahwa peristiwa kekerasan yang terjadi, sebagian adalah juga karena kehamilan korban. Padahal, apabila ditelusuri lebih jauh, kehamilan itu sendiri bisa terjadi dalam berbagai latar, misalnya bujuk rayu, pemerkosaan, dan lain sebagainya. Singkat kata, dengan menempatkan praanggapan yang demikian, sekali lagi terlihat tidak adanya empati dari jurnalis terhadap nasib malang yang dialami oleh korban.

\section{Sintaksis}

Elemen sintaksis dalam berita tersebut tidak banyak muncul. Namun dalam paragraf terakhir, elemen itu muncul melalui penggunaan ungkapan ternyata oh ternyata, yang dipakai untuk menjembatani pernyataan sebelum-sebelumnya dengan fakta bahwa pelaku telah merencanakan kejahatan itu sebelumnya. Secara leksikal, "ternyata oh ternyata" sebenarnya tidak bermakna apaapa. Namun ketika ungkapan itu dimasukkan dalam tubuh berita, maka kesan yang muncul adalah bahwa peristiwa itu sebagai sesuatu yang layak untuk ditertawakan, bukan sebagai sesuatu yang serius. Penggunaan kata tersebut juga semakin menjelaskan bahwa jurnalis menganggap bahwa kemalangan yang dialami korban adalah sesuatu yang patut ditertawakan. Seksualitas perempuan adalah obyek yang berhak ditertawakan oleh jurnalis, dan perilaku perkosaan bukanlah hal yang serius. 


\section{Stilistik}

Opini dan imajinasi penulis yang masuk dalam berita di atas, terlihat ketika dikaji elemen stilistiknya. Dalam berita tersebut, terdapat beberapa pilihan kata yang muncul dari imajinasi penulis, di antaranya adalah menyusun siasat, puyeng, kalap, edan, dibogem, dan ternyata oh ternyata.

Pemilihan kata tersebut memiliki makna yang kasar dan seolah menggambarkan bahwa kekerasan seksual yang dilakukan oleh pelaku adalah sesuatu yang biasa dan hampirhampir tidak penting. Karena pesan yang disampaikan demikian, maka pilihan-pilihan kata itu berdampak terhadap persepsi yang timbul di benak pembaca, juga tidak akan jauh berbeda, yakni tidak menganggap duka yang dialami korban pemerkosaan adalah sesuatu yang perlu mendapat perhatian sangat serius. Selain itu, penggunaan kata-kata tersebut, menunjukkan tidak adanya empati penulis terhadap perempuan yang menjadi korban dalam berita itu.

\section{Retoris}

Absennya empati terhadap korban kekerasan seksual dalam berita di atas juga muncul saat dikaji elemen retorisnya. Dalam berita itu, sama sekali tidak ditampilkan bagaimana citra korban. Dengan kata lain, citra korban sengaja disembunyikan. Kesengajaan menyembunyikan citra korban ini bisa terjadi karena berbagai hal, misalnya tidak adanya akses untuk mewawancarai korban, atau keengganan jurnalis untuk menggali lebih dalam citra korban tersebut. Padahal, dengan menonjolkan citra korban akan memungkinkan pembaca untuk memiliki persepsi empatik terhadapkorbandan peristiwa yang dialaminya. Namun hal itu tidak dilakukan, sebaliknya, yang ditonjolkan adalah bagaimana kronologi peristiwa tersebut dieksploitasi sedemikian rupa sehingga menyebabkan pembaca seolaholah sedang disuguhi sebuah citra kekerasan. Dengan penonojolan kronologi itu, pembaca seolah dibawa untuk menyaksikan sendiri dan berfantasi bagaimana kekerasan seksual sedang berlangsung, namun pada akhirnya hal ini tidak menimbulkan empati apa-apa dari pembaca terhadap korban.

\section{Wajah Kekerasan Seksual di Media Daring}

Dari pembedahan yang telah dilakukan terhadap tiga teks berita tersebut, nampak bahwa kekerasan seksual yang dialami oleh perempuan merupakan bagian dari objek ekpoitasi media pada seksualitas perempuan. Sebagai objek eksploitasi, maka empati yang semestinya diberikan kepada korban tidak hilang dalam teks. Kalaupun dalam tiga berita di atas terdapat ungkapan-ungkapan atau diksi-diksi bernada empati, tetapi yang paling banyak ditonjolkan dalam ketiganya adalah kronologi secara deskriptif yang memungkinkan pembaca turut hadir dalam peristiwa itu sebagai penonton dan menikmati suguhan objek kemalangan perempuan.

Dari konten berita yang telah dianalisis juga terlihat bahwa ada kecenderungan bahwa jurnalis tidak memberikan ruang bagi perempuan yang menjadi korban kekerasan seksual, atau sekurang-kurangnya kepada keluarga maupun kuasa hukum korban untuk menceritakan pengalaman kekerasan seksual itu berdasarkan dimensi ceritera perempuan (korban). Sebaliknya, informasi-informasi yang disajikan melalui teks lebih banyak bersumber dari aparat penegak hukum dan pelaku dari kekerasan itu sendiri.

Temuan ini menunjukkan minimnya empati jurnalis terhadap perempuan. Minimnya empati ini bisa terjadi karena beberapa faktor. Pertama, pengaruh nilai-nilai budaya yang dianut oleh jurnalis. Nilai-nilai budaya di dalam pribadi jurnalis ini tumbuh karena pengaruh oleh nilai-nilai budaya yang ada di sekitarnya. Sebagai contoh, dalam berita berjudul "Pacar Hamil Tiga Bulan, Dihajar Sampai tak Berdaya, Lalu Diperkosa", lokasi kejadian adalah di Kecamatan Nongsa, Kota Batam, Kepulauan Riau. Sedangkan di Kota Batam, merujuk pada penelitian yang dilakukan Widayatun (2008:86), adalah kawasan perbatasan yang marak dengan prostitusi dan trafficking. Selain sebagai tempat perekrutan industri seks internasional, Batam juga 
memiliki beberapa tempat yang lekat dengan industri seks seperti rumah bordil, karaoke, dan panti pijat. Di antaranya di kawasan Jodoh, Batam Center, dan Nagoya. Tumbuhnya kota Batam sebagai wilayah yang lekat dengan industri seksual terselubung mempengaruhi cara pandang masyarakat dan pelaku media di sana terhadap seksualitas. Perempuan sering dianggap sebagai sebuah obyek atau komoditi seksual. Oleh karena itu, ketika jurnalis lokal berhadapan dengan kasus-kasus kekerasan seksual terhadap perempuan, cara pandang mereka terhadap perempuan yang menjadi korban masih belum dapat terlepas sepenuhnya dari nilai-nilai yang dibawanya. Pada akhirnya, hal ini pun termanifestasikan pada konten-konten yang mereka buat dalam pemberitaan.

Demikian pula dengan berita berjudul "Cinta Ditolak, Pria 45 Tahun Perkosa, Bunuh Lalu Bakar Balita" yang memiliki latar tempat di Kabupaten Sangatta, Provinsi Kutai Timur. Dikutip dari laman berita kliksangatta. com yang pada 15 April 2016 menayangkan berita berjudul "Darurat, Kekerasan Seksual Anak di Kutai Timur Tembus 23 Kasus", terlihat bahwa kasus kekerasan seksual di kawasan Kutai Timur termasuk yang sangat tinggi. Lebih jauh, dengan menyoroti kondisi sosial masyarakat Sangatta yang masuk dalam Provinsi Kutai Timur dan merupakan kawasan pertambangan, ada kecenderungan bahwa perempuan di kawasan pertambangan memiliki posisi yang lemah dalam masyarakat. Hal ini selaras dengan temuan Maimunah (2014) yang dituangkan dalam esai berjudul Perempuan di Wilayah Tambang: Melawan NeoKolonialisme Baru yang menyebut bahwa perempuan di kawasan pertambangan sangat tergantung secara ekonomi kepada lakilaki karena wilayah kelolanya menyempit, bahkan hilang, setelah dikuasai oleh korporasi pertambangan. Meskipun masih harus diteliti lebih jauh, tetapi kondisi yang demikian bukan tidak mungkin berpengaruh terhadap produk jurnalistik seputar kekerasan seksual terhadap perempuan yang dibuat oleh jurnalis dan media lokal setempat.
Dalam berita berjudul "Cewek ABG Diperkosa Usai Digerebek Berdua-duaan", tampak ada ketakutan di benak jurnalis yang menulis berita terhadap sosok pelaku serta ormas yang diketuainya. Hal ini terlihat dari penggunaan inisial untuk menunjuk pelaku dan korban sekaligus. Selain itu, dalam berita ini jurnalis juga tidak menyebutkan nama ormas yang diketuai oleh pelaku meskipun sebenarnya nama ormas itu sendiri merupakan sebuah fakta yang tidak dapat dihindari. Dalam hal ini, memang ada upaya jurnalis untuk melindungi identitas korban. Di sisi lain, jurnalis ternyata juga berusaha menyembunyikan identitas pelaku yang kemudian bisa dimaknai ada kekhawatiran dari jurnalis bahwa berita tersebut akan dipermasalahkan oleh ormas yang bersangkutan apabila nama ormas disebutkan. Dengan demikian, dalam berita ini ada kecenderungan jurnalis masih tak bisa dilepaskan dari bayang-bayang kekuasaan yang mengitarinya sehingga kemudian berusaha melindungi identitas pelaku.

Kedua, hilangnya empati jurnalis dalam berita-berita di atas semakin diperkuat oleh cara kerja media daring yang lebih menonjolkan kecepatan tayang. Hal ini pada akhirnya menyebabkan jurnalis enggan untuk menggali lebih banyak informasi dari berbagai sumber, utamanya dari pihak perempuan yang menjadi korban. Hal ini bisa terlihat dari rentang waktu antara tanggal peristiwa berlangsung maupun tanggal narasumber diwawancarai dengan tanggal penayangan berita. Dalam berita pertama berjudul Cewek ABG Diperkosa Usai Digerebek Berdua-duaan misalnya, peristiwa berlangsung pada 20 Maret 2016, sementara beritanya ditayangkan pada 24 Maret 2016, atau terdapat rentan waktu selama tiga hari. Sedangkan dalam berita kedua berjudul "Cinta Ditolak, Pria 45 Tahun Perkosa, Bunuh Lalu Bakar Balita", tidak dijelaskan kapan peristiwa itu berlangsung, namun wawancara dengan satu-satunya narasumber dilakukan pada 11 Agustus 2016. Sedangkan tanggal penayangan berita 
dilakukan sehari setelahnya, atau pada 12 Agustus 2016. Dengan demikian hanya ada selisih waktu satu hari antara tanggal penggalian informasi hingga tanggal penayangan. Terakhir, pada berita ketiga berjudul "Pacar Hamil 3 Bulan, Dihajar Sampai tak Berdaya, Lalu Diperkosa", yang ditayangkan pada 17 Agustus 2016, meski tidak disebutkan kapan wawancaranya berlangsung, namun disampaikan bahwa peristiwa itu terjadi pada 16 Juli 2016. Dengan demikian, ada selisih satu bulan antara tanggal berlangsungnya peristiwa hingga saat ditayangkannya berita tersebut. Dibanding dua berita sebelumnya, rentang waktu pada berita inilah yang paling lama.

Dengan minimnya waktu yang dimiliki oleh jurnalis yang menyusun berita tersebut, tentu saja akan kesulitan untuk menyusun sebuah berita dari kegiatan reportase mendalam (depth reporting) yang memungkinkan seluruh narasumber mendapat ruang untuk berbicara dan seluruh data dapat diperoleh. Seperti disampaikan oleh Santana (2009:285), reportase mendalam membutuhkan waktu yang panjang. Untuk melakukan reportase semacam itu, jurnalis harus meluangkan banyak waktu untuk menghimpun data dan mewawancarai narasumber-narasumber yang relevan.

Jurnalisme yang demikian tidak sesuai dengan konsep media daring di mana setiap media berlomba-lomba untuk menjadi yang tercepat dalam menyuguhkan informasi. Dalam perlombaan paling cepat memberikan informasi ini, dampaknya adalah dinomorduakannya prinsip akurasi atau ketepatan. Hal ini selaras dengan pernyataan Robert I Berkman dan Christoper A Shumway dalam buku Digital Dilemmas for Online Media Professionals (2003) seperti dikutip oleh Haryanto (2014:5) bahwa desakan dalam media online untuk tampil atau untuk dipublikasikan secepat-cepatnya berhadapan dengan masalah menyampaikan berita sebenar-benarnya atau seakurat-akuratnya.

Dalam kaitannya dengan tiga berita yang sebelumnya telah dibedah, minimnya empati terhadap perempuan yang menjadi korban kekerasan seksual bukanlah satu-satunya faktor yang mengkonstruksi seksualitas perempuan dalam posisi marginal. Dalam mengolah dan menggali faktor lain ini, diperlukan penelitian yang lebih mendalam yang melibatkan wawancara dengan jurnalisjurnalis yang melakukan penulisan berita tersebut. Akan tetapi, membandingkan rentang waktu antara tanggal peristiwa berlangsung, tanggal wawancara dilakukan, dan tanggal berita ditayangkan, sementara dapat disimpulkan bahwa keterbatasan waktu dalam kerja jurnalistik di era media daring telah menyebabkan empati terhadap perempuan korban kekerasan seksual dipinggirkan. Fakta yang terjadi adalah sebaliknya, untuk membuat pembaca tertarik untuk meng-klik berita yang dibuat, maka disusunlah kalimatkalimat yang bombastis meskipun itu harus mengesampingkan perasaan para korban dan terkesan mengeksploitasi tragedi yang mereka alami.

\section{SIMPULAN}

Dari paparan di atas dapat disimpulkan beberapa hal berkaitan konstruksi seksualitas perempuan dalam media daring. Pertama, media daring dengan karakteristiknya turut serta melestarikan ideologi yang tidak peka terhadap perempuan. Utamanya dalam mengonstruksi seksualitas perempuan secara sistemik, media menggambarkan perempuan dalam ketidakberdayaannya menghadapi dominasi laki-laki (maskulin).

Kedua, media secara stimultan memberikan penggambaran seksualitas perempuan sebagai objek yang sahih dimiliki laki-laki. Ketiga berita yang telah dianalisis menggambarkan dengan jelas bagaimana seksualitas perempuan dipahami sebagai bagian dari hal yang dikendalikan laki-laki.

Ketiga, media daring dengan karakteristiknya yang menuntut mengunggah berita dengan cepat, menyebabkan jurnalis mengesampingkan empati terhadap perempuan. Reportase disusun tidak akurat sehingga cenderung mengedapankan fantasi dan imajinasi dari reporter ataupun editor. Semata-mata demi kepentingan iklan dan kapital, media 
cenderung membombastiskan isi berita dan berlebihan dalam memberitakan perempuan.

Masa depan media daring menjadi tugas seluruh stakeholder untuk mengawalnya. Regulasi berbasis etika perlu disusun ulang dan penegakan hukum yang berpihak pada perempuan perlu dikedepankan demi masa depan media daring yang ramah terhadap perempuan, bukan yang marah terhadap perempuan.

Dalam menjabarkan faktor-faktor lain yang mempengaruhi ketidakpekaan jurnalis dalam menulis berita, perlu dilakukan penelitian lebih mendalam dengan metode etnometodologi maupun etnografi komunikasi dalam membedah factor- faktor lain dalam penyusunan berita.

\section{DAFTAR PUSTAKA}

Aditya, B.J. 2016. Menjadi Sintas: Tindakan \& Upaya Pencegahan dan Pemulihan Kekerasan Seksual. Jurnal Perempuan Vol 21 (2): 47 - 64.

Ansor, M., \& Meutia, C. I. 2016. Jilbab dan Reproduksi Identitas Perempuan Kristen Ruang Publik Sekolah Aceh. Jurnal Kawistara, 6(2), 157-174.

Brooks, Dwight E. dan Hebert, Lisa P. 2006. "Gender, Race, and Media Representation". In Bonnie J. Dow and Julia T. Wood (Eds.) The SAGE Handbook of Gender and Communication Thousand Oaks, CA: Sage Publications.

Butler, J. 2011a. Gender Trouble: Feminism and the Subversion of Identity. New York: Routledge.

Butler, J. 2011b. Bodies that Matter: On The Discursive Limits of Sex. Taylor \& Francis.

Haryanto, I. 2014. Jurnalisme Era Digital: Tantangan Industri Media Abad 21. Jakarta: Kompas.

Jackson, S., dan Jones, J. 2009. Pengantar Teori-teori Feminis Kontemporer. Yogyakarta: Jalasutra.
JPNN. 2015. “Cewek ABG Diperkosa Usai Digrebek Berdua-duaan" JPNN. Internet. < http://www.jpnn.com/ $\mathrm{read} / 2016 / 03 / 24 / 365548 /$ CewekABG-Diperkosa-Usai-DigerebekBerdua-duaan>. Diakses pada tanggal 23 Agustus 2016.

JPNN. 2016. “Cinta Ditolak, Pria 45 Tahun Perkosa, Bunuh Lalu Bakar Balita" JPNN. Internet. < http://www.jpnn. com/news/cinta-ditolak-pria-45tahun-perkosa-bunuh-lalu-bakarbalita>. Diakses pada tanggal 23 Agustus 2016.

JPNN. 2016. “Pacar Hamil 3 Bulan, Dihajar Sampai tak Berdaya, Lalu Diperkosa" JPNN. Internet. < http://www.jpnn. com/read/2016/08/17/461522/ Pacar-Hamil-3-Bulan-DihajarS a m pai-tak-B e rda y a - LaluDiperkosa>. Diakses pada tanggal 23 Agustus 2016.

Kliksangatta. 2016. "Darurat Kekerasan Seksual Anak di Kutai Timur Tembus 23 Kasus" Kliksangatta. Internet. < http://kliksangatta.com/ berita2888-darurat-kekerasan-seksualanak-di-kutai-timur-tembus-23kasus.html>. Diakses pada tanggal 22 Februari 2017.

Kuntoro, 2008. Analisis Wacana Tritis: Teori Van Dijk dalam Kajian Teks Media Massa. Leksika Vol.2 (2), 45-55.

Lehtonen, S. 2007. Feminist Critical Discourse Analysis and Children's Fantasy Fiction Modelling a New Approach. Finland: University of Jyväskylä.

Maimunah, Siti. 2014. "Dampak Pertambangan." Down to Earth Indonesia. Internet. http:/ / www.downtoearthindonesia.org/id/story/dampakpertambangan $>$ Diakses pada tanggal 21 Februari 2017.

Margianto, J. H. dan Syaefullah, A. 2012. Media Online: Pembaca, Laba, dan Etika. Jakarta: Aliansi Jurnalis Independen Indonesia. 
Poerwandari, K. 2016. "Pembuktian Keperawanan", Pencarian Kenikmatan Diri dan Kontrol atas Perempuan: Psikoanalisis Pelaku Kekerasan Seksual. Jurnal Perempuan Vol 21 (2): 20-46.

Santana K.S. 2009. Jurnalisme Investigasi. Jakarta: Obor.

Santi, S. 2006. Khitan Perempuan: Legitimasi Agama dan Budaya Atas Kekerasan dan Pengendalian Tubuh Perempuan. Jurnal Forum Ilmiah Indonusa Vol 3 (1): 1-7.

Sobur, A. 2001. Analisis Teks Media. Bandung: Rosda.

Suriasumantri, J.S. 2013. Filsafat Ilmu: Sebuah Pengantar Populer. Jakarta: Pustaka Sinar Harapan.

Susilo, D. 2014. Jurnalisme Tidak Peka Gender: Studi Analisis Wacana Pemberitaan Perempuan Oleh Media Online Tribunnews.com. In
R. Ida (Ed). Prosiding Post-Graduate Roundtable Universitas Airlangga Surabaya 2014, 6 Desember 2014: 1725.

Susilo, D. 2015. Konstruksi Maskulinitas dalam Teks Media: Analisis Wacana Maskulinitas dalam Berita Pemerkosaan di Situs Berita Online. In Katubi and Imelda (Eds). International Conference of Language, Culture, and Society 2015, 25-26 November 2015: 220-227.

Undang-Undang Nomor 35 Tahun 2014 tentang Perubahan atas UndangUndang Nomor 23 Tahun 2002 tentang Perlindungan Anak.

Widayatun. 2008. Trafficking di Wilayah Perbatasan. Jurnal Masyarakat $\mathcal{E}$ Budaya Vol.10 (1), 81-101.

Wood, J. T. 2005. Gendered Lives: Communication, Gender, and Culture. Boston: Wadsworth Publishing.

Van Dijk, T.A. 2001. Discourse, Ideology, and Context. Folia Linguistica XXXV(1): $11-40$. 